Materiales de Construcción

Vol. 70, Issue 339, July-September 2020, e222

ISSN-L: 0465-2746

https://doi.org/10.3989/mc.2020.13619

\title{
Alkali activation of recycled ceramic aggregates from construction and demolition wastes
}

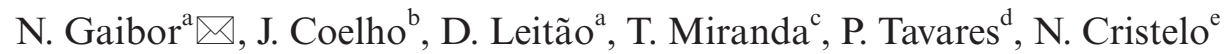 \\ a. CTAC, Department of Civil Engineering, Azurém Campus, University of Minho, (Guimarães, Portugal) \\ b. School of Engineering of the University of Minho, Azurém Campus, (Guimarães, Portugal) \\ c. ISISE, Institute for Science and Innovation for Bio-Sustainability (IB-S), Department of Civil Engineering, \\ University of Minho, (Guimarães, Portugal) \\ d. CQ-VR, Centro de Química - Vila Real, Department of Chemistry, \\ University of Trás-os-Montes e Alto Douro, (Vila Real, Portugal) \\ e. CQ-VR, Centro de Química - Vila Real, Department of Engineering, \\ University of Trás-os-Montes e Alto Douro, (Vila Real, Portugal) \\ $\triangle$ normygaibor@gmail.com
}

\begin{abstract}
Environmental concerns are becoming increasingly more significant worldwide, thus creating the urgent need for new sustainable alternatives in the industrial sector. The present study assesses the fundamental properties of ceramic residue (CR) originated by demolition operations, specifically, the floor and wall tiles and sanitaryware furniture, for further incorporation in the construction sector, namely in alkali-activated binders, mixed with other better-known precursors - fly ash (FA) and ladle furnace slag (LFS). Different CR/FA and CR/LFS weight ratios were considered and analyzed by mechanical behavior and microstructural analysis, which included uniaxial compression strength (UCS) tests, Scanning Electron Microscopy (SEM), X-ray Energy Dispersive Analyser (EDX), X-ray diffraction (XRD) and Fourier Transform Infrared Spectroscopy (FTIR). Results obtained showed that the combination of CR and FA or LFS, activated with sodium silicate, produced UCS values higher than $20 \mathrm{MPa}$ and $59 \mathrm{MPa}$, respectively, after 90 days curing.
\end{abstract}

KEYWORDS: Ceramic; Alkali-activated cement; Waste treatment; Mechanical properties; Physical properties.

Citation/Citar como: Gaibor, N.; Coelho, J.; Leitão, D.; Miranda, T.; Tavares, P.; Cristelo, N. (2020) Alkali activation of recycled ceramic aggregates from construction and demolition wastes. Mater. Construcc. 70 [339], e222 https://doi. org/10.3989/mc.2020.13619

RESUMEN: Activación alcalina de áridos cerámicos reciclados provenientes de residuos de construcción y demolición. Globalmente, las preocupaciones ambientales son cada vez más significativas, creando así la necesidad urgente de nuevas alternativas sostenibles en el sector industrial. El presente estudio evalúa las propiedades fundamentales de los residuos cerámicos $(\mathrm{CR})$ provenientes de demolición, para ser reincorporados en el sector de la construcción, principalmente como ligantes activados alcalinamente, mezclados con otros precursores más conocidos: cenizas volantes (FA) y escorias de horno de cuchara (LFS). Se consideraron diferentes relaciones de peso CR/FA y CR/LFS, se analizó el comportamiento mecánico y se realizó un análisis microestructural, incluyendo pruebas de resistencia a la compresión (UCS), microscopía electrónica de barrido (SEM), análisis por energías dispersivas de rayos X (EDX), Rayos-X (XRD) y espectroscopía infrarroja por transformada de Fourier (FTIR). Los resultados mostraron que, a 90 días de curado, la combinación de CR y FA o LFS activada con silicato de sodio produjo valores de UCS superiores a $20 \mathrm{MPa}$ y $59 \mathrm{MPa}$, respectivamente.

PALABRAS CLAVE: Cerámica; Cemento activado alcalinamente; Tratamiento de residuos; Propiedades mecánicas; Propiedades físicas.

ORCID ID: N. Gaibor (https://orcid.org/0000-0002-0003-8901); J. Coelho (https://orcid.org/0000-0002-9959-4907); D. Leitão (https://orcid.org/0000-0003-0841-7954); T. Miranda (https://orcid.org/0000-0003-4054-6860); P. Tavares (https://orcid.org/0000-0001-7589-1299); N. Cristelo (https://orcid.org/0000-0002-3600-1094)

Copyright: (C) 2020 CSIC. This is an open-access article distributed under the terms of the Creative Commons Attribution 4.0 International (CC BY 4.0) License 


\section{INTRODUCTION}

Worldwide environmental concerns are becoming increasingly more significant. The shortage of natural resources and the increasing levels of greenhouse gas emissions to the atmosphere frames a scenario that inevitably, forces mankind to create new sustainable alternatives for the industrial sector. The use of different kinds of industrial waste and residues as alternative materials in the construction industry can contribute in a very effective way to such sustainability.

On the other hand, the generation of construction and demolition wastes (CDW) and, specifically, the generation of brick and ceramic waste fractions, is accelerating globally due to increasing renovation and reconstruction of old buildings, which constitute about $45 \%$ of the total CDW (1). In 2014, the total waste generated by all activities for the twenty-eight members of the European Union (EU-28), reached 2503 million tons (being the highest amount during the last 10 years reported). The generation of CDW increased by $57.2 \%$ during the 2004-2014 period, thus showing an inversed trend, when compared with other sectors. For instance, the generation of manufacturing waste, in the same period, decreased by $32.2 \%$. The numbers confirm the relevance of reinforcing waste valorization in order to propose new management and treatment alternatives (2).

The ceramic industry is plentifully located in different parts of the world. China and Europe are the world leaders in ceramic production. It is also exported to other regions due to its durability and variety in design. In the European Union (EU), the ceramic industry represents approximately $25 \%$ of global production. The major producing countries in the EU are Italy, Germany, Spain, France, the United Kingdom, Portugal, and Austria (3). Except for the ceramic industry's vast economic benefits, it causes adverse environmental impacts. Ceramic industries produce around one-third of the total ceramic production which is disposal without any further treatment. This solid waste leads to severe environmental pollution and significant land location (4). The search for sustainable solutions that take advantage to waste materials from the ceramic industry is currently a crucial challenge for this sector.

The construction industry shows an increasing demand for new, bold, sustainable structural and non-structural materials. Ceramic products represent a significant part in the construction industry and, therefore, the requirements in terms of raw materials are also raising. Natural resources are facing a decrease with time due to uncontrolled uses. It is worth noting that progress in the incorporation of alternative materials might be a useful way to diminish the use of natural resources by recycling the ceramic residue coming out from CDW (5).
However, recycling and using such wastes in newer construction purposes is not a fresh concept; it has been practiced since the Roman Empire when people reused stones obtained from former roads in the construction of new ones (6). Still, the construction industry represents a very significant possibility to apply, using direct or indirect strategies, significant percentages of several types of by-products and/or wastes. Some common examples are fly ash, CDW or blast furnace slags, which have been used as a cement or aggregate replacement, embankment fill, road, and railway pavement foundation, among others. It is thought that there is room for the further use of increased volumes of these residues and, also, to introduce new types of industrial byproducts in the production chain (7). Some studies related to waste incorporation in the civil construction are showing up next and along with the present document.

Ceramic residues are hard, durable, extremely resistant to chemical, physical and biological degradations and highly thermally stable (4). Ceramic producers and the construction sector are looking for valuable waste disposal ways due to an increase in the pile-up of them. There is a wide research work in the development of sustainable alkali-activated building materials using industrial ceramic wastes, such as bricks manufacturing $(8,9)$, hybrid binder based on ceramic tile wastes (10), ceramic materials from ecofriendly geopolymer precursors (11), ceramic roof tiles (12), among others. As it can be evidenced, for the synthesis of geo-polymers, waste ceramics as an efficient alternative have been employed (13). Huseien et al. (14) stated the geopolymer industries can use the ceramic wastes safely without requiring any remarkable change in the production and application process. The author studied the performance of waste ceramic powder (WCP), at different content of $50 \%, 60 \%$, and $70 \%$, as a binder on the mechanical and microstructure properties of alkali-activated mortars (AAMs), mixed with ground blast furnace slag (GBFS) and fly ash (FA). The specimens were left for 24 hours at ambient temperature $(27 \pm 1.5){ }^{\circ} \mathrm{C}$ and relative humidity of $75 \%$, then tested at ages of 1,3 , $7,28,56,90,180$ and 360 days. Results showed a compressive strength higher than $70 \mathrm{MPa}$ at the age of 28 days. While Hwang et al. (1) used waste red clay brick powder (WBP) and waste ceramic powder (WCP) as source materials to develop an alkaliactivated paste. The ceramic waste was $60 \%$ of the total weight of the precursors, and the remaining $40 \%$ contained fly ash (FA) and ground granulated blast furnace slag (GGBFS). The alkali-activator solutions were $\mathrm{Na}_{2} \mathrm{SiO}_{3}$ and $\mathrm{NaOH}$. Samples were cured at ambient temperature for $3,7,28$, and 56 days. The alkali-activated paste with WBP presented higher compressive strength (36-70 MPa). It was due to the finer particle size and higher $\mathrm{CaO}$ 
content of the WBP as compared to the WCP. Reig et al. (15), reported the use of tile ceramic waste as both a recycled aggregate (TCWA) and a precursor (TCWP). Samples were cured at $65^{\circ} \mathrm{C}$ for 3 days. The mechanical properties of the mortars prepared with TCWA reached $53 \mathrm{MPa}$ at $65^{\circ} \mathrm{C}$ for 28 days. According to Rakhimova et al. (16) who has studied the potential of introducing WBP in alkali-activated slag cement attested the combination of both improve the compressive and flexural strength. However, it highly depends on the sodium concentration (percentage of $\mathrm{Na}_{2} \mathrm{O}$ ), silica modulus $\left(\mathrm{SiO}_{2} / \mathrm{Na}_{2} \mathrm{O}\right)$ and curing methods. The sustainability of mortars fabricated from alkali-activated waste ceramic tile powder and fly ash (FA), exposed to various hostile environments, was investigated by Huseien et al. (17). The assessment in terms of durability suggested that freezing-thawing resistance improved by increasing the FA content in the mortar. It also improved the performance in terms of sulfate and acid environments, as well as decreased energy consumption, financial cost and $\mathrm{CO}_{2}$ emission. The same authors also studied the performance of this material when exposed to elevated temperatures, concluding that the mechanical strength was enhanced with the increase in ceramic powder content, from 50 to $70 \%$ (18).

This work focuses on the reusability of the CDW ceramic residue fraction, such as floor and wall tiles and sanitaryware. It is due to their availability and generation trend. This paper aim is to know the ceramic residue fundamental properties for further incorporation. In this way, the behavior of ceramic residue exhibit in alkaline activated systems mix with other industrial wastes (fly ash or ladle furnace slag) was analyzed. In addition, the mechanical behavior test was also conducted. The research was complemented by a microstructural analysis, including Scanning Electron Microscopy (SEM), X-ray Energy Dispersive Analysis (EDX), X-ray diffraction (XRD) and Fourier Transform Infrared Spectroscopy (FTIR).

\section{MATERIALS AND METHODS}

\subsection{Materials}

The pastes studied within the scope of the present research are composed of different wastes ceramic residue (CR), fly ash (FA) or ladle furnace slag (LFS); and alkaline activators in solution form - sodium hydroxide $(\mathrm{NaOH})$ or sodium silicate $\left(\mathrm{Na}_{2} \mathrm{SiO}_{3}\right)$. The CR (Figure 1a) was provided by a Portuguese licensed waste management operator. Based on the technical sheet, it is part of a batch from demolition operations and, specifically, from the selected floor and wall tiles and sanitaryware furniture. After dried, it was mechanically milled (MCR, Figure 1b), for 32 hours, in a purposely built ball mill, with an increased capacity of $5 \mathrm{~kg}$. The FA (Figure 1c) was obtained from a Portuguese thermo-electric power plant, owned by the company $P E G O P$, and the LFS (Figure 1d) was supplied by the Portuguese ironwork company Megasa, located in Maia, in the north of Portugal.

The particle size distribution (PSD) of all precursors (CR, MCR, FA, and LFS), presented in Figure 2, were determined by laser granulometry, on a Sympatec Helos BF analyzer, able to measure particles from 0.9 to $175 \mu \mathrm{m}$ and using Fraunhofer diffraction theory. The analyses were conducted after a 5-min ultrasonic bath, on a water-ethanol solution, for increased particle dispersion. The PSD of the original CR revealed a poorly graded material, with all particles above $0.075 \mathrm{~mm}$ (fine/course reference line). This scenario was significantly modified after the milling process, which produced a more wellgraded material, with a fine fraction of approximately $35 \%$.

The chemical composition of the original wastes was determined by X-ray fluorescence (Table 1). The main constituents of the CR are silica $(70.98 \%)$ and alumina $(17.87 \%)$, with a calcium content of $3.72 \%$. The FA showed a similar composition, with significant silica (56.11\%) and alumina $(21.44 \%)$ contents, although with a lower calcium content of $1.30 \%$. The composition of the LFS contains an important calcium content $(49.48 \%)$, while its significant silica content $(18.79 \%)$ is, nonetheless, the lowest of the three wastes.

The mineralogy of the original materials precursors and the subsequent pastes was assessed on a PANalytical X'Pert Pro diffractometer, fitted with an $X^{\prime}$ Celerator detector and secondary monochromator, using $\mathrm{CuK} \alpha$ radiation at $40 \mathrm{kV}$ and $30 \mathrm{~mA}$. The scans were acquired with Bragg-Brentano geometry, covering a $2 \theta$ range between 7 and $85^{\circ}$, with a nominal step size of $0.017^{\circ}$ and $100 \mathrm{~s} / \mathrm{step}$. In the case of the CR, LFS and resulting pastes, phase quantification was performed on diffraction patterns applying Rietveld (19), with the code Highscore Plus 4.8. The values are presented in weight percentage, in Table 2. For the FA refinement, the code PowderCell 2.4 (20) was applied instead. The amorphous phase was simulated through the Le Bail model (21). Volume percentages were converted into weight percentages using the respective density. Figure 3 presents the X-ray diffractograms, showing that the CR is essentially quartz, although several other minor phases were also detected, as sillimanite, oligoclase, mullite, and anorthite. The main crystalline phases identified in the FA were quartz, mullite, hematite, and graphite. The last one shares the main peak in the same location as quartz, halo between 25 and $27^{\circ}(2 \theta)$. While the LFS presents several crystalline phases, namely calcio, olivine, andradite, calcite, cuspidine, titanite, and larnite, it presented mostly crystalline structures. The slag presents a slight halo, 


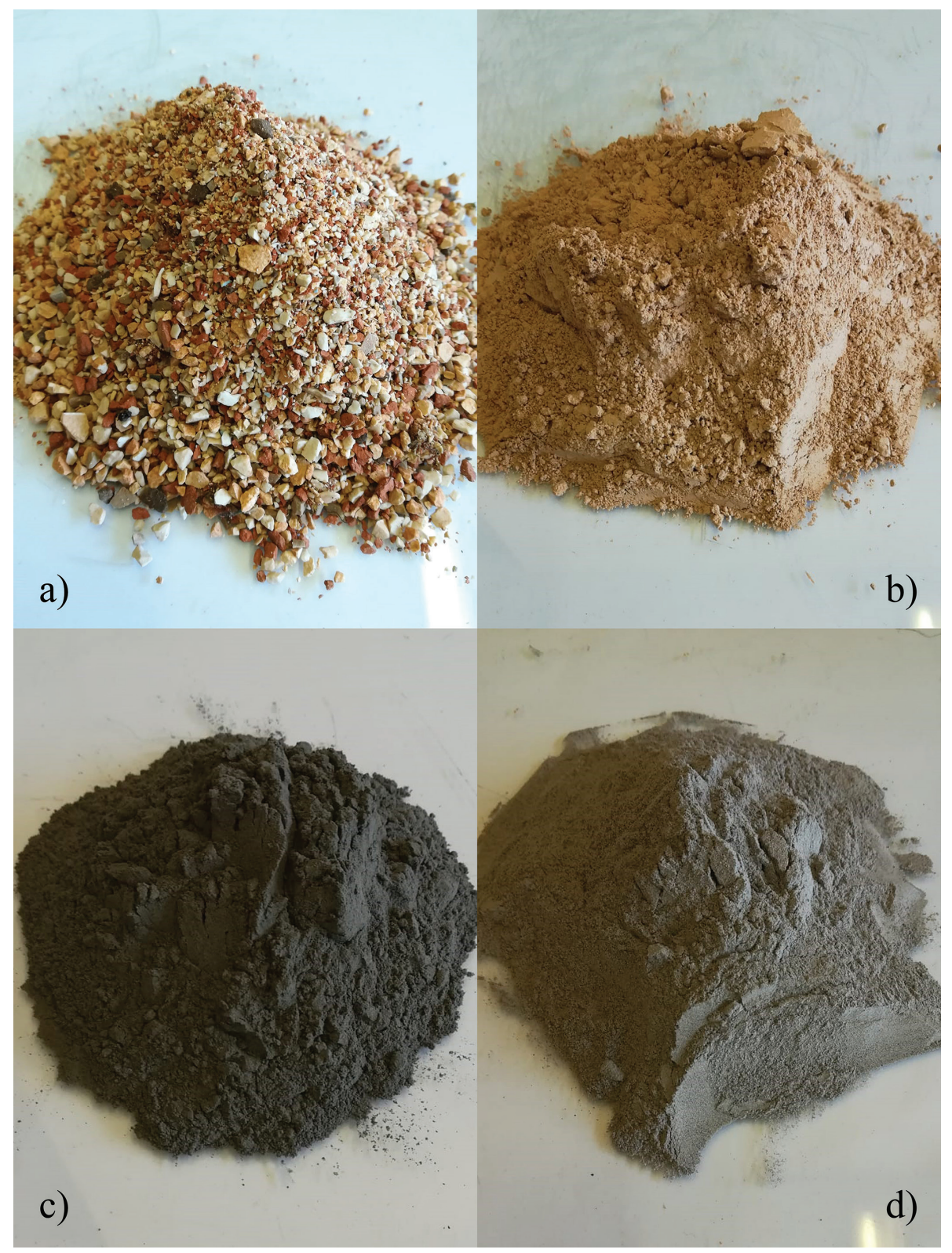

FIGURE 1. Precursors used in the laboratory experiments: a) original ceramic residue (CR); b) ceramic residue (MCR) milled for 32 hours; c) fly ash (FA); d) ladle furnace slag (LFS).

between 27 and $40^{\circ}(2 \theta)$, characteristic of vitreous/ amorphous materials (22), while the fly ash and ceramic residue showed a similar halo, although between $2 \theta \approx[25-30]^{\circ}$.

Sodium hydroxide $(\mathrm{SH})$ and sodium silicate (SS), in solution form, were used as activators throughout this study. The SH was prepared 4 to $6 \mathrm{~h}$ before the fabrication of the pastes, with a concentration of 8 molal, using deionized water. The sodium silicate had a unit weight of $1.464 \mathrm{~g} / \mathrm{cm}^{3}$ at $20^{\circ} \mathrm{C}$, a $\mathrm{SiO}_{2} / \mathrm{Na}_{2} \mathrm{O}$ weight ratio of 2.0 (molar oxide ratio of 2.063) and a $\mathrm{Na}_{2} \mathrm{O}$ concentration in the solution of $13.0 \%$.

\subsection{Preparation and development of the experimental work}

The composition of the mixtures was defined based on the results of a preliminary test where the variation of the solid/liquid ratio between the precursor and the activator determined the appropriate ratio to obtain better workability of the mixtures. The performance of sodium hydroxide $(\mathrm{SH})$ or sodium silicate (SS) were studied in separate experiments. Each experimental setup included a parallel treatment of both precursors and covered the same alkali activator concentrations (SH or SS). 


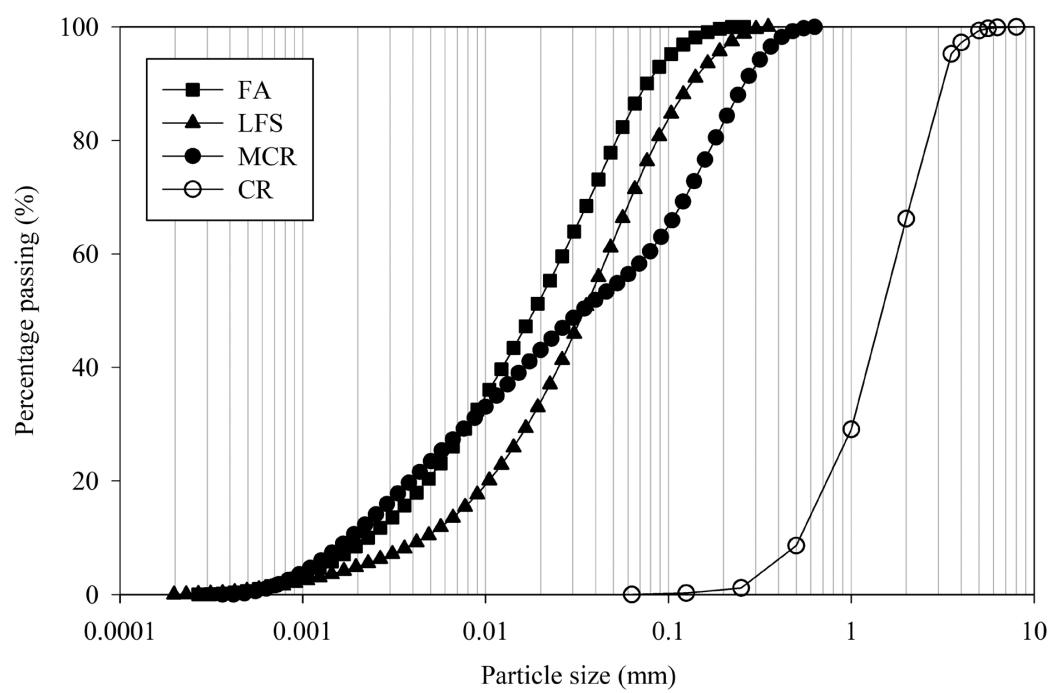

FIGURE 2. Particle size distribution (PSD).

TABLE 1. Chemical composition of the CR, FA, and LFS (\% wt).

\begin{tabular}{lcccccccccccccc}
\hline Material & $\mathrm{Al}_{2} \mathbf{O}_{3}$ & $\mathbf{C a O}$ & $\mathrm{Cr}_{2} \mathbf{O}_{3}$ & $\mathrm{Fe}_{2} \mathbf{O}_{3}$ & $\mathrm{~K}_{2} \mathbf{O}$ & $\mathbf{M g O}$ & $\mathrm{MnO}$ & $\mathrm{Na}_{2} \mathbf{O}$ & $\mathbf{P}_{2} \mathrm{O}_{5}$ & $\mathrm{SiO}_{2}$ & $\mathrm{SO}_{3}$ & $\mathrm{TiO}_{2}$ & $\mathrm{ZnO}$ & $\mathbf{O}$ thers \\
\hline CR & 17.87 & 3.72 & - & 1.20 & 3.18 & 1.31 & - & 1.27 & - & 70.98 & - & 0.47 & - & - \\
FA & 21.44 & 1.30 & 0.06 & 8.20 & 2.81 & 1.46 & 0.07 & 1.12 & 0.25 & 56.11 & 0.66 & 1.15 & 0.03 & 5.34 \\
LFS & 7.39 & 49.48 & 0.68 & 10.07 & 0.03 & 5.41 & 1.43 & 0.13 & 0.07 & 18.79 & 3.42 & 0.40 & 1.25 & 1.45 \\
\hline
\end{tabular}

TABLE 2. Minerals quantification in starting materials, ceramic residue (CR) - milled for 32 hours; Fly Ash (FA); ladle furnace slag (LFS), (\% wt).

\begin{tabular}{|c|c|c|c|c|c|c|c|c|c|c|c|c|c|c|c|c|}
\hline Material & $\mathbf{S}$ & O & $\mathbf{Q}$ & Mu & A & Ma & $\mathbf{H}$ & G & Co & $\mathrm{Cu}$ & $\mathrm{Ca}$ & $\mathrm{Ti}$ & $\mathbf{L a}$ & An & Amorphous & $\mathbf{R}_{\mathrm{wp}}(\%)$ \\
\hline $\mathrm{CR}$ & $\begin{array}{r}2.3 \\
\pm 0.8\end{array}$ & $\begin{array}{r}8.2 \\
\pm 0.9\end{array}$ & $\begin{array}{r}62.3 \\
\pm 2.0\end{array}$ & $\begin{array}{r}19.8 \\
\pm 1.5\end{array}$ & $\begin{array}{r}7.4 \\
\pm 1.5\end{array}$ & - & - & - & - & - & - & - & - & - & - & 9.3 \\
\hline FA & - & - & $\begin{array}{r}9.7 \\
\pm 0.9\end{array}$ & $\begin{array}{l}10.2 \\
\pm 0.9\end{array}$ & & $\begin{array}{r}1.0 \\
\pm 0.1\end{array}$ & $\begin{array}{r}0.7 \\
\pm 0.1\end{array}$ & $\begin{array}{r}1.3 \\
\pm 0.2\end{array}$ & - & - & - & - & - & - & $77.1 \pm 4$ & 7.7 \\
\hline LFS & - & - & - & - & & - & - & - & $\begin{array}{l}49.2 \\
\pm 2\end{array}$ & $\begin{array}{r}13.4 \\
\pm 0.9\end{array}$ & $\begin{array}{r}2.8 \\
\pm 0.2\end{array}$ & $\begin{array}{r}1.3 \\
\pm 0.2\end{array}$ & $\begin{array}{l}22.5 \\
\pm 1\end{array}$ & $\begin{array}{r}10.7 \\
\pm 0.9\end{array}$ & - & 8.1 \\
\hline
\end{tabular}

S: Sillimanite; O: Oligoclase; Q: Quartz; Mu: Mullite; A: Anorthite; Ma: Magnetite; H: Hematite; G: Graphite; Co: Calcio Olivina; Cu: Cuspidine; Ca: Calcite; Ti: Titanite; La: Larnite; An: Andradite

Table 3 presents the studied pastes, including its respective activator/precursor ratio. CR was tested without the addition of an additional precursor (FA or LFS), to assess the possibility of direct activation, which would translate into more economical and less logistical demanding pastes.

The sodium hydroxide was prepared 4 to 6 hours before use because it generates an exothermic reaction which needs is needs to cool down. The activator temperature at the time of the mixing was $20^{\circ} \mathrm{C} \pm 1^{\circ} \mathrm{C}$. A mechanic mixing process followed, for a period of 3 minutes, complemented by manual homogenization, with the help of a spatula (whenever required, the mechanical homogenization period was extended for 2 minutes).
The homogenized paste was then poured into cubic stainless-steel molds and mechanically compacted for 2 minutes. Three cubic specimens of $40 \mathrm{x}$ $40 \times 40 \mathrm{~mm}^{3}$ (nominal dimensions) were fabricated for each paste, and for each curing period. The initial curing period lasted 1 day at $70^{\circ} \mathrm{C}$, with the pastes still inside the molds. It was followed by 14, 28 and 90 days curing at ambient temperature and humidity $20-23{ }^{\circ} \mathrm{C}$ and around $60 \% \mathrm{RH}$, respectively. After measured and weighed, each specimen was then subjected to a uniaxial compression strength test (UCS), on a servo-hydraulic testing machine, using three different actuators, with load capacities of 40,100 and $120 \mathrm{kN}$. These tests were carried out under monotonic displacement control, at a rate of 
$6 \cdot$ N. Gaibor et al.

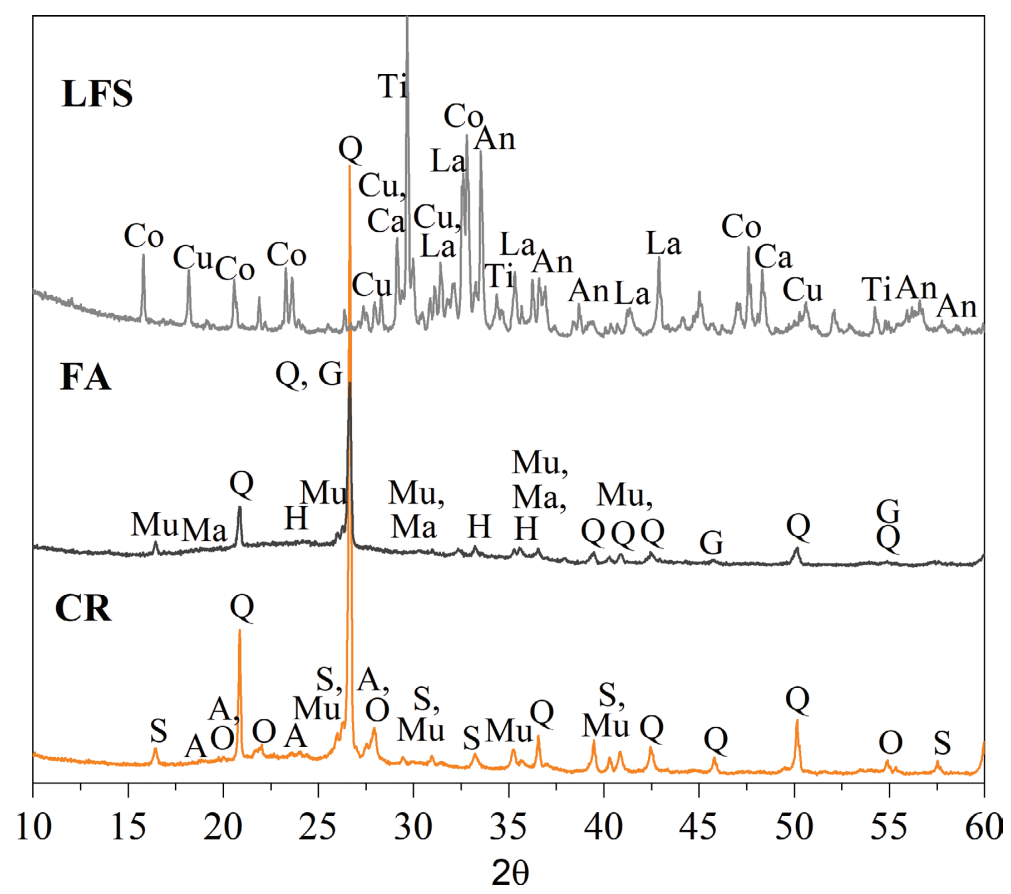

FIGURE 3. XRD spectra of the ceramic residue (CR) - milled for 32 hours; Fly Ash (FA); ladle furnace slag (LFS) (S: Sillimanite; O: Oligoclase; Q: Quartz; Mu: Mullite; A: Anorthite; Ma: Magnetite; H: Hematite; G: Graphite; Co: Calcio Olivina; Cu: Cuspidine; Ca: Calcite; Ti: Titanite; La: Larnite; An: Andradite).

TABLE 3. Identification and characterization of the tested pastes.

\begin{tabular}{|c|c|c|c|c|c|c|c|c|c|}
\hline \multirow{2}{*}{$\begin{array}{l}\text { Paste } \\
\text { ID }\end{array}$} & \multicolumn{3}{|c|}{ Precursor } & \multirow[b]{2}{*}{ Activ } & \multirow{2}{*}{$\begin{array}{c}\text { Precurs. I } \\
\text { Activ. } \\
\text { (wt. ratio) }\end{array}$} & \multirow{2}{*}{$\begin{array}{c}\mathrm{CaO} / \\
\mathrm{SiO}_{2}\end{array}$} & \multirow{2}{*}{$\begin{array}{c}\mathrm{Na}_{2} \mathrm{O} / \\
\mathrm{Al}_{2} \mathrm{O}_{3} \\
\end{array}$} & \multirow{2}{*}{$\begin{array}{l}\mathrm{SiO}_{2} \mathrm{I} \\
\mathrm{Al}_{2} \mathrm{O}_{3}\end{array}$} & \multirow{2}{*}{$\begin{array}{l}\mathrm{SiO}_{2} \\
\mathrm{Na}_{2} \mathrm{O}\end{array}$} \\
\hline & CR & FA & LFS & & & & & & \\
\hline \multirow[t]{5}{*}{ M1 } & 100 & 0 & - & $\mathrm{SH} 8 \mathrm{~m}$ & 0.32 & 0.05 & 0.41 & 3.97 & 9.74 \\
\hline & 75 & 25 & - & & 0.34 & 0.05 & 0.41 & 3.58 & 8.82 \\
\hline & 50 & 50 & - & & 0.36 & 0.04 & 0.41 & 3.23 & 7.98 \\
\hline & 25 & 75 & - & & 0.38 & 0.03 & 0.40 & 2.91 & 7.21 \\
\hline & 0 & 100 & - & & 0.40 & 0.02 & 0.40 & 2.62 & 6.49 \\
\hline \multirow[t]{5}{*}{ M2 } & 100 & 0 & - & SS & 0.40 & 0.05 & 0.36 & 4.55 & 12.58 \\
\hline & 75 & 25 & - & & 0.43 & 0.04 & 0.36 & 4.18 & 11.50 \\
\hline & 50 & 50 & - & & 0.46 & 0.03 & 0.37 & 3.84 & 10.52 \\
\hline & 25 & 75 & - & & 0.49 & 0.03 & 0.37 & 3.53 & 9.64 \\
\hline & 0 & 100 & - & & 0.52 & 0.02 & 0.37 & 3.25 & 8.84 \\
\hline \multirow[t]{5}{*}{ M3 } & 100 & - & 0 & $\mathrm{SH} 8 \mathrm{~m}$ & 0.32 & 0.05 & 0.41 & 3.97 & 9.74 \\
\hline & 75 & - & 25 & & 0.34 & 0.26 & 0.48 & 3.80 & 7.85 \\
\hline & 50 & - & 50 & & 0.36 & 0.59 & 0.59 & 3.55 & 6.01 \\
\hline & 25 & - & 75 & & 0.38 & 1.19 & 0.76 & 3.18 & 4.21 \\
\hline & 0 & - & 100 & & 0.40 & 2.63 & 1.04 & 2.54 & 2.46 \\
\hline \multirow[t]{5}{*}{ M4 } & 100 & - & 0 & SS & 0.40 & 0.05 & 0.36 & 4.55 & 12.58 \\
\hline & 75 & - & 25 & & 0.43 & 0.22 & 0.43 & 4.53 & 10.51 \\
\hline & 50 & - & 50 & & 0.46 & 0.47 & 0.53 & 4.50 & 8.51 \\
\hline & 25 & - & 75 & & 0.49 & 0.85 & 0.68 & 4.45 & 6.57 \\
\hline & 0 & - & 100 & & 0.52 & 1.53 & 0.93 & 4.37 & 4.69 \\
\hline
\end{tabular}


$0.6 \mathrm{~mm} / \mathrm{min}$, and stress-strain curves were plotted for all tests performed.

The present research was complemented by microstructural analysis, which included Scanning Electron Microscopy (SEM), X-ray Energy Dispersive Spectroscopy (EDX), X-ray diffraction (XRD) and Fourier Transform Infrared Spectroscopy (FTIR). SEM analyses were developed on a FEI Quanta 400 scanning electron microscope, at $30 \mathrm{kV}$, in low vacuum mode, with partial pressure inside the chamber (1.3 mbar), avoiding the deposition of a conductive layer. An EDS analyzer, from EDAX, allowed a chemical analysis of the elements present in each sample, using the same spectrum acquisition time and a ZAF correction model.

The FTIR spectra were acquired using a Thermo Scientific Nicolet iS50 FTIR spectrometer, resorting to an ATR (Attenuated Total Reflectance) accessory with a diamond crystal. The instrument was controlled by the Omnic software package, version 9.2.28, from Thermo Fisher Scientific Inc. A spectrum range of 4000 to $400 \mathrm{~cm}-1$ was defined, with a resolution of $4 \mathrm{~cm}^{-1}$ and 64 number of scans by 90 seconds each sample.

\section{RESULTS AND DISCUSSION}

\subsection{Compressive strength}

The uniaxial compressive strength (UCS) results are presented in Figure 4, showing the data for the pastes prepared with CR and FA, and Figure 5, showing the data for the pastes with CR and LFS. Although the aim of the UCS tests was to assess the effectiveness of the CR, pastes with an increasing amount of FA and LFS (up to, and including, a 100\% content for each case) are also presented, so that a threshold could be established, and direct comparison could easily be made. Curing periods of $1,14,28$ and 90 days are presented, yet it is important to remember, at this stage, that the 1-day curing specimens were exclusively cured at $70^{\circ} \mathrm{C}$, while the remaining specimens were cured for 1 day, at $70^{\circ} \mathrm{C}$, while the remaining curing was developed at ambient temperature $\left(20-23^{\circ} \mathrm{C}\right)$.

In general, curing time increased the UCS, regardless of the type of precursor (CR+FA or CR+LFS) or activator (SH or SS). Also evident are the higher strength values obtained with the SS-based pastes, comparatively to the $\mathrm{SH}$-based specimens, irrespective of whether the precursor combination. Finally, the third and most relevant observation is the higher UCS achieved by the CR+LFS precursor combination, when compared with the CR+FA blend.

For the CR+FA combination, activated with $\mathrm{SH}$, the most effective solution was the 50\% CR and 50\% FA. When SS was used, the proportion 75\% CR and $25 \%$ FA achieved the highest UCS value after 90 days. However, it is significant, considering that the purpose of the present study is the disposal of the ceramic residue, that the $100 \% \mathrm{CR}$ paste (which represents the highest possible volume of CR incorporated) showed the highest UCS for the CR+FA combination after 1, 14 and 28 days, and showed only a marginally lower UCS after 90 days. This suggests that the use of FA is not absolutely required, which would represent a significant gain in terms of economic and logistical efforts.

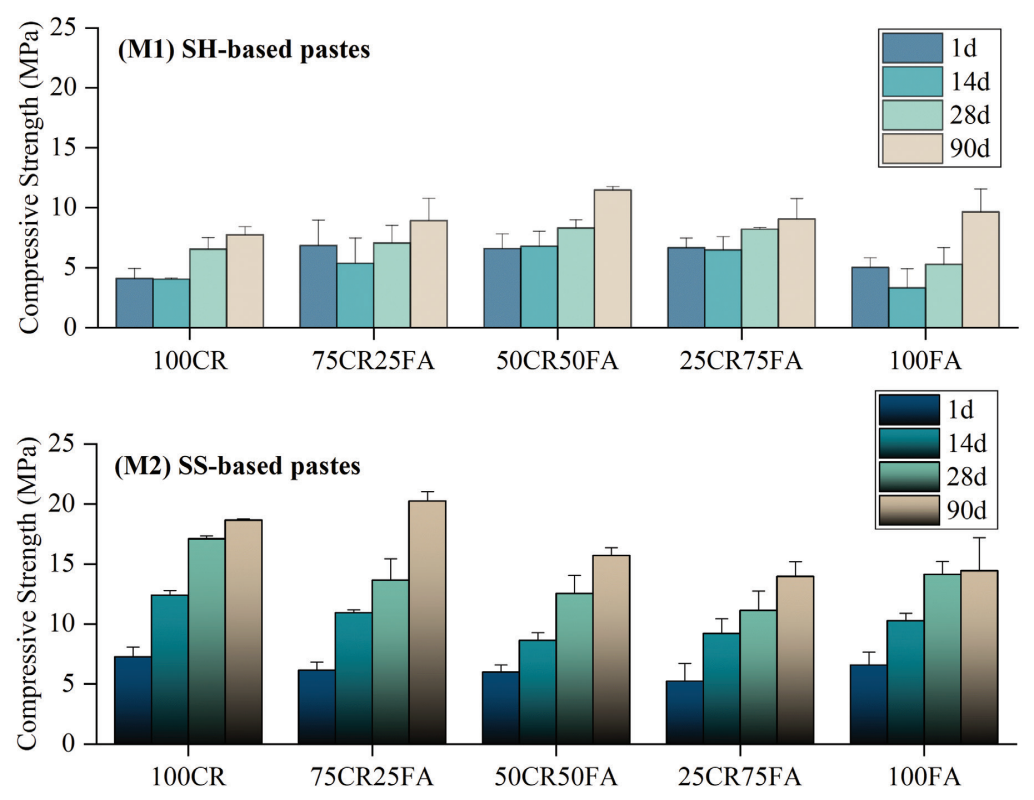

FIGURE 4. UCS of the CR+FA pastes, prepared with SH (M1) or SS (M2) after 1, 14, 28, 90 days curing. 
$8 \cdot$ N. Gaibor et al.

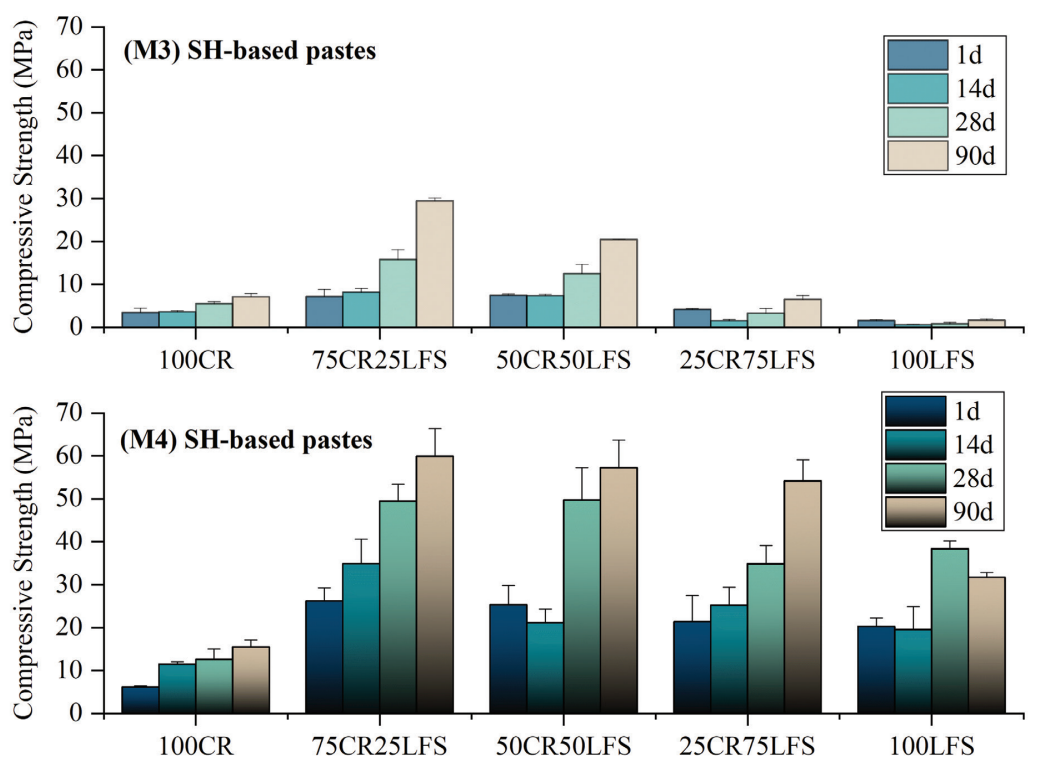

Figure 5. UCS of the CR+LFS pastes, prepared with SH (M3) or SS (M4), after 1, 14, 28, 90 days curing.

Regarding the CR+LFS combination, the scenario was slightly different for the SH-based pastes, with the $75 \% \mathrm{CR}+25 \% \mathrm{LFS}$ representing the higher UCS. Another significant difference was the extent of such strength increase, at the 90-day mark: the addition of $50 \%$ FA produced an UCS improvement of $1.9 x$, relatively to the $100 \% \mathrm{CR}$, while the addition of $25 \%$ LFS produced an UCS improvement of $4.6 x$, relatively to the same $100 \% \mathrm{CR}$ paste. For the SS-based pastes, the CR+LFS scenario was similar to the one described for the CR+FA pastes, i.e. the addition of $25 \%$ of the alternative precursor represented the most performing combination for both cases. However, the $75 \% \mathrm{CR}+25 \% \mathrm{LFS}$ paste now showed higher UCS values for all curing periods, and not just for 90 days. Not only that, but the difference, at the 90-day mark, between the $100 \% \mathrm{CR}$ and the $75 \% \mathrm{CR}+25 \% \mathrm{LFS}$ was clearly more significant $(3.15 \mathrm{x})$ than the difference between the $100 \% \mathrm{CR}$ and the $75 \% \mathrm{CR}+25 \% \mathrm{FA}(1.1 \mathrm{x})$.

\subsection{Mineralogical and microstructural characterization}

The pastes with the highest strength values from each set (M1, M2, M3, and M4), corresponding in most cases to the composition $75 \% \mathrm{CR}+25 \%$ (FA or LFS), were selected for microstructural analyses, using XRD, SEM/EDS and FTIR to characterize the cementitious materials developed during their respective reactions throughout the initial 90 days of curing.

Figure 6 shows the XRD diffractograms of the different pastes, 75CR+25FA (SH or SS) (M1 and $\mathrm{M} 2$ ) and $75 \mathrm{CR}+25 \mathrm{LFS}$ (SH or SS) (M3 and M4).
The products resulting from the activation reaction present similar peaks which were also found in the initial materials, suggesting that the equivalent phases are essentially inert to the alkaline activation process. In cases where a slight reduction of their intensity is detected, it is due to the material dilution (induced by the blend with the activator). The presence of mullite in M1 (25.1 \pm 1.5$)$ and M2 $(23.2 \pm 1.5)$ is somewhat higher in comparison to the other two mixtures (see Table 4), fundamentally influenced by the outset constituents, CR and FA with significant $\mathrm{Si}$ content (Table 1). Crystalline phases of $\mathrm{Mu}$ in the pastes were also displaced in range, from $28-30^{\circ}(2 \theta)$ to 30 to $35^{\circ}(2 \theta)$ in contrast to CR and FA XDR diffractograms (Figure 3). These variations are a consequence of the formation of amorphous phases in the aluminosilicate gel, which will partially crystalize, in time (zeolitic precursor) (22-24). The anorthite (A) was identified in the four mixtures since the CR is the major component. However, higher A content was evidenced in M3 (16.5 \pm 1.1$)$ and M4 (15.0 \pm 1.1$)$ (Table 4) as a result of having a precursor (LFS) with high $\mathrm{Ca}$ content. In all blends, the main peak was registered at approximately $26^{\circ}(2 \theta)$, corresponding to quartz, which makes it the most relevant crystalline phase. It also worth to mention that for neither case the $\mathrm{Na}_{2} \mathrm{CO}_{3} \cdot \mathrm{H} 2 \mathrm{O}$ (thermonatrite) phase was found, denoting that the $\mathrm{Na}$ was retained in the gel, thus not migrating to the surface.

The same four pastes, cured at ambient temperature for 90 days, were analyzed with SEM. The chemical composition was also obtained, with 10 points per image. Figure 7 shows SEM images of selected samples, enabling an understanding of the 


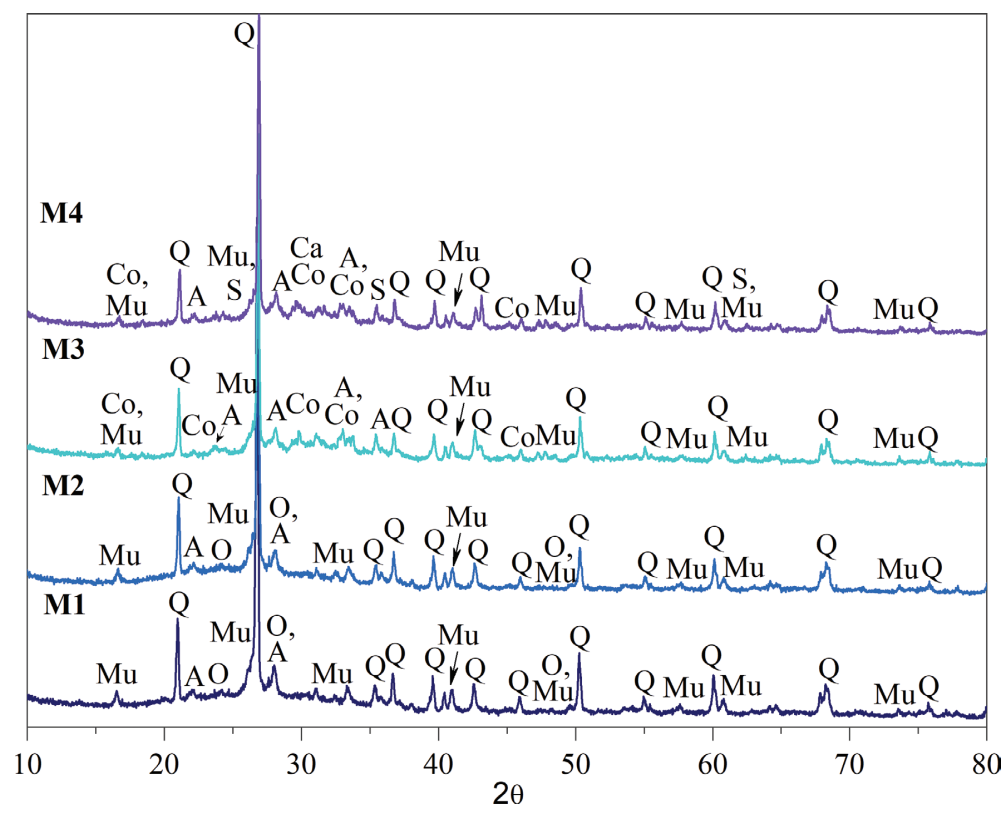

FIGURE 6. XRD patterns of the 75CR-25FA/SH or SS mixtures (M1 and M2) and 75CR-25LFS/SH or SS mixtures (M3 and M4), after 90 days curing time (O: Oligoclase; Q: Quartz; Mu: Mullite; A: Anorthite; Co: Calcio Olivina; Ca: Calcite; S: Sillimanite).

TABLE 4. Minerals quantification of the 75CR-25FA/SH or SS mixtures (M1 and M2) and 75CR-25LFS/SH or SS mixtures (M3 and M4), after 90 days curing time ( $\% \mathrm{wt})$.

\begin{tabular}{lcccccccc}
\hline Material & $\mathbf{O}$ & $\mathbf{Q}$ & $\mathbf{M u}$ & $\mathbf{A}$ & $\mathbf{C o}$ & $\mathbf{C a}$ & $\mathbf{S}$ & $\mathbf{R}_{\mathrm{wp}}(\mathbf{\%})$ \\
\hline M1 & $9.1 \pm 0.9$ & $55.9 \pm 2.0$ & $25.1 \pm 1.5$ & $9.9 \pm 0.9$ & - & - & - & 8.4 \\
M2 & $13.8 \pm 1.1$ & $53.4 \pm 2.0$ & $23.2 \pm 1.5$ & $9.7 \pm 0.9$ & - & - & - & 8.4 \\
M3 & - & $46.9 \pm 2.0$ & $21.6 \pm 1.5$ & $16.5 \pm 1.1$ & $13.8 \pm 1.1$ & $1.2 \pm 0.1$ & 10.0 \\
M4 & - & $48.6 \pm 2.0$ & $19.2 \pm 1.5$ & $15.0 \pm 1.1$ & $10.8 \pm 1.0$ & $2.3 \pm 0.2$ & $4.1 \pm 0.4$ & 9.9 \\
\hline
\end{tabular}

O: Oligoclase; Q: Quartz; Mu: Mullite; A: Anorthite; Co: Calcio Olivina; Ca: Calcite; S: Sillimanite

morphology and general distribution of the different constituents in the mixtures. Base on all the images exhibited, it can be said that the resulting paste is generally compacted, homogeneous and with low porosity. In M1(75CR-25FA/SH) is possible to observe several FA (points A) or CR (points C) unreacted particles covered with reaction products. However, in M2 (75CR-25FA/SS), even after 90 days, an unreacted particle without any signs of $\mathrm{Na}$ 'attack', can still be detected (points A). It was also observed a slightly higher Ca content in the M2 paste, compared with the M1, which might result from a higher dissolution degree. Regarding the type of gel developed, a N-A-S-H type was detected (point *) when using FA as a complementary precursor, regardless of the activator solution used (SH or SS).

A similar situation can be seen for the 75CR-25FA/ SH (M3) and 75CR-25LFS/SH (M4) pastes. Some small LFS (points B) and CR (points C) unreacted particles are distinguished. The most significant aspect of the M4 paste was the Ca heterogeneous distribution throughout the sample, which can be due to the incidence of particles with an important presence of $\mathrm{Ca}$. Concerning the type of gel developed, and when LFS in combination with CR were used, its calcium content naturally affected the composition of the gel, which can be classified as a $\mathrm{N}$, C-A-S-H, if SH acted as activator (M3), or C-A-S-H (points *) $(25,26)$, when the precursors were instead activated with SS (M4). The general chemical composition of the four studied mixtures is summarized in Table 5, where is presented the average value of the analyzed points and its standard deviation (SD).

Figure 8, shows the FTIR spectra for the starting materials (LFS, CR, and FA) as well as the M1 (75CR25FA), M2 (75CR25FA), M3 (75CR25FA), and M4 (75CR25FA) pastes activated with SH or SS, after 90 days of curing, which present a set of bands centered in the frequency range between [400 - 2000] $\mathrm{cm}^{-1}$. Different behavior in the spectra of each of the materials is observed, for LFS two main bands are detected at $840 \mathrm{~cm}^{-1}$ and $1040 \mathrm{~cm}^{-1}$, which are generally associated at deformation vibration of carbonates $\left(\mathrm{CO}_{3}{ }^{2-}\right), \mathrm{C}-\mathrm{O}$, while the $560 \mathrm{~cm}^{-1}$ band is 

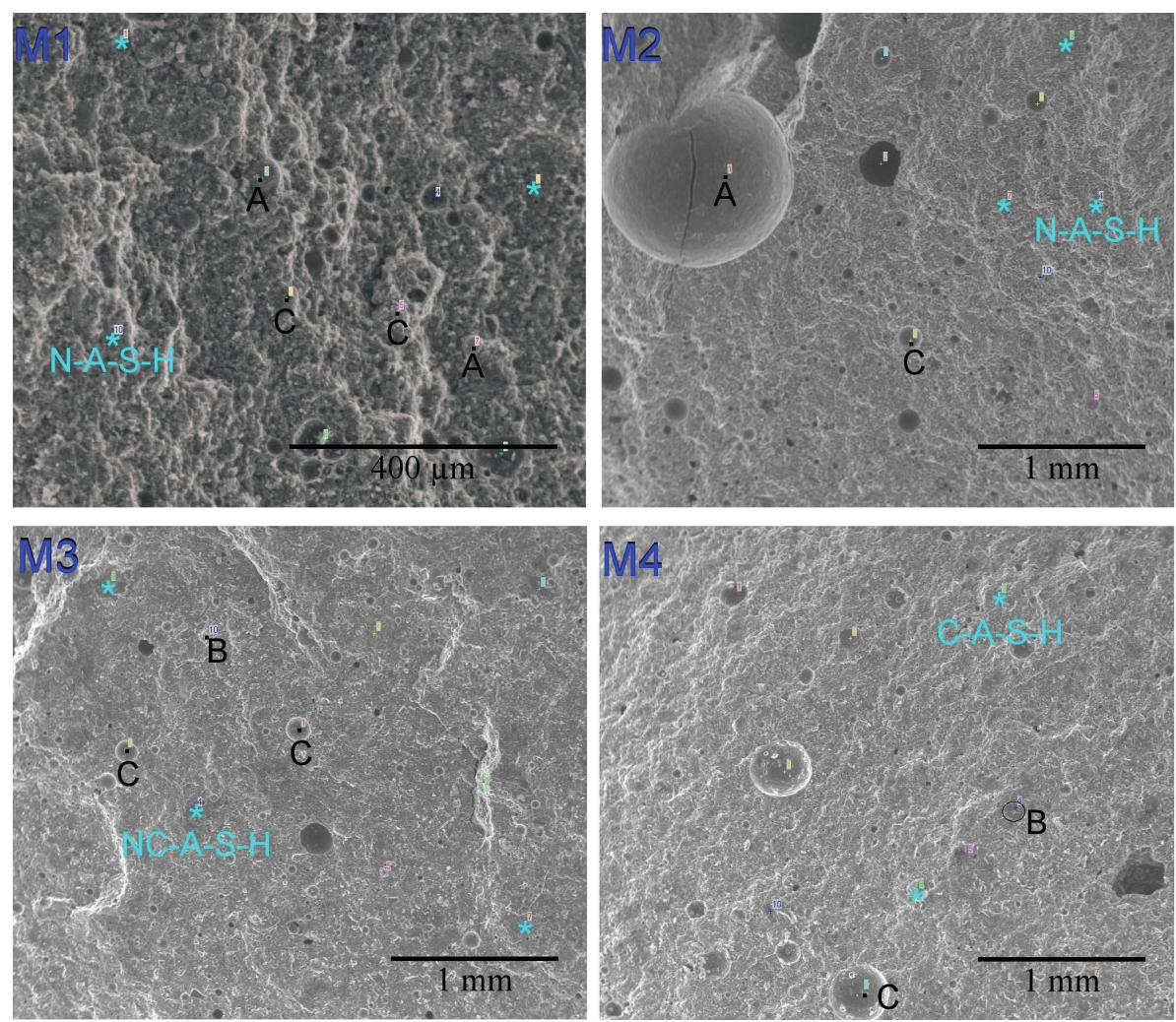

FIGURE 7. SEM images of 75CR-25FA/SH or SS mixtures (M1 and M2) and 75CR-25LFS/SH or SS mixtures (M3 and M4), after 90 days curing time.

TABLE 5. Chemical composition of mixtures at 90 days curing time, $\% \mathrm{Wt}$, (SD in parentheses).

\begin{tabular}{lcccc}
\hline & M1 75CR-25FA/SH & M2 75CR-25FA/SS & M3 75CR-25LFS/SH & M4 75CR-25LFS/SS \\
\hline $\mathrm{Na}_{2} \mathrm{O}$ & $6.66(1.93)$ & $15.06(3.47)$ & $10.49(1.04)$ & $5.24(1.77)$ \\
$\mathrm{MgO}$ & $0.84(0.26)$ & $1.47(0.82)$ & $1.79(0.91)$ & $1.80(1.61)$ \\
$\mathrm{Al}_{2} \mathrm{O}_{3}$ & $19.53(5.44)$ & $14.58(1.33)$ & $16.65(4.43)$ & $12.26(4.86)$ \\
$\mathrm{SiO}_{2}$ & $63.35(3.59)$ & $57.92(5.34)$ & $52.12(3.12)$ & $59.09(11.30)$ \\
$\mathrm{SO}_{3}$ & - & - & $2.22(1.47)$ & $2.55(3.32)$ \\
$\mathrm{K}_{2} \mathrm{O}$ & $5.81(1.24)$ & $2.61(0.61)$ & $2.44(0.26)$ & $2.03(1.03)$ \\
$\mathrm{CaO}$ & $1.84(1.03)$ & $2.70(0.59)$ & $11.44(3.07)$ & $15.52(11.73)$ \\
$\mathrm{TiO}_{2}$ & $0.52(0.32)$ & $0.84(0.33)$ & $0.66(0.23)$ & $0.57(0.29)$ \\
$\mathrm{MnO}_{\mathrm{Fe}} \mathrm{O}_{3}$ & - & - & - & $0.11(0.26)$ \\
$\mathrm{CaO} / \mathrm{SiO}_{2}$ & $1.46(0.50)$ & $4.82(4.67)$ & $2.21(2.15)$ & $0.83(0.42)$ \\
$\mathrm{NaO}_{/} \mathrm{Al}_{2} \mathrm{O}_{3}$ & $0.01(0.00)$ & $0.02(0.01)$ & $0.22(0.06)$ & $0.27(0.36)$ \\
$\mathrm{SiO}_{2} / \mathrm{Al}_{2} \mathrm{O}_{3}$ & $0.36(0.14)$ & $1.05(0.28)$ & $0.67(0.18)$ & $0.48(0.27)$ \\
$\mathrm{SiO}_{2} / \mathrm{Na}_{2} \mathrm{O}$ & $3.44(0.84)$ & $3.97(0.18)$ & $3.31(0.82)$ & $5.41(2.03)$ \\
& $10.24(2.86)$ & $4.06(1.18)$ & $5.01(0.59)$ & $12.62(4.74)$ \\
\hline
\end{tabular}

linked with the Al-O-Al bond and $490 \mathrm{~cm}^{-1}$ and 440 $\mathrm{cm}^{-1}$ are associated with $\mathrm{O}-\mathrm{Si}-\mathrm{O}$ connections. The fly ash (FA) evidences a wide main band at $1015 \mathrm{~cm}^{-1}$, this is associated with $\mathrm{Si}-\mathrm{O}-\mathrm{Si}$ or $\mathrm{Si}-\mathrm{O}-\mathrm{Al}$ bonds, while the $790 \mathrm{~cm}^{-1}$ and $420 \mathrm{~cm}^{-1}$ bands are related with $\mathrm{Si}-\mathrm{O}$ bonds (quartz). In addition, the presence of another band that records at $550 \mathrm{~cm}^{-1}$ is associated with the octahedral aluminum (Al-O-Al bonds) of the mullite (27), previously distinguished in this material by XRD, (see Figure 3). The CR sample shows a deep and wide main band that appears around $1040 \mathrm{~cm}^{-1}$. This is typical of asymmetric 


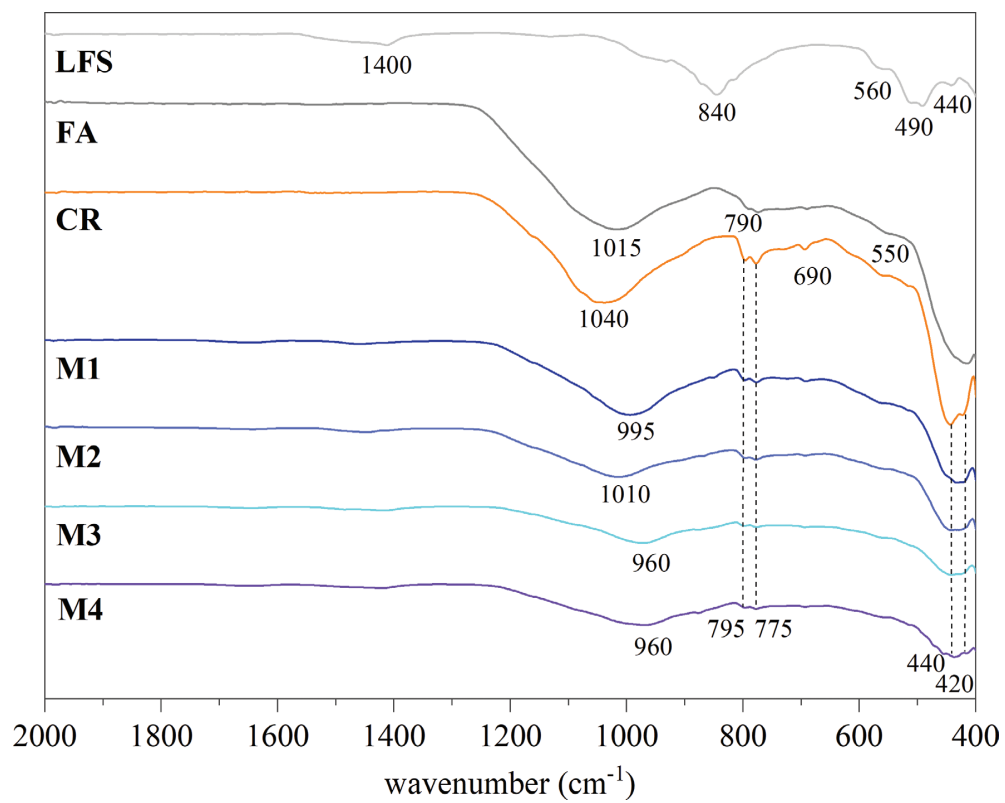

FIGURE 8. FTIR spectra of starting materials, the ladle furnace slag (LFS); ceramic residue (MCR) - milled for 32 hours; fly ash (FA), and 75CR-25FA/SH or SS mixtures (M1 and M2) and 75CR-25LFS/SH or SS mixtures (M3 and M4), after 90 days curing time.

tension vibration, related to $\mathrm{Si}-\mathrm{O}-\mathrm{Si}$ or $\mathrm{Si}-\mathrm{O}-\mathrm{Al}$, confirming some crystallinity of the material. The bands at $795 \mathrm{~cm}^{-1}, 775 \mathrm{~cm}^{-1}$, and $420 \mathrm{~cm}^{-1}$ correspond to O-Si-O bonds (quartz).

The FTIR spectra of the four different mixtures are also presented in Figure 8, where basically the characteristic vibration bands of the main components of the starting materials are shown. At the end of the 90 days of curing, the most significant change was the displacement of the main CR band $\left(1040 \mathrm{~cm}^{-1}\right)$, for shorter wavelengths, which is attributed to a structural reorganization caused by the formation of reaction products (28). But, in mixtures of the studied proportions of $\mathrm{M} 1$ and $\mathrm{M} 2$, the displacement was between $995 \mathrm{~cm}^{-1}$ and $1010 \mathrm{~cm}^{-1}$, which is related to the formation of the typical N-A-S-H gel, while M3 and M4 shifted around $960 \mathrm{~cm}^{-1}$, this translation is connected to the presence of LFS in the composition, promoting the formation of $\mathrm{N}, \mathrm{C}-\mathrm{A}-\mathrm{S}-\mathrm{H}$ type gel.

\section{CONCLUSIONS}

The fundamental properties of the ceramic residue from an operator with Portuguese license and their performance in combination with fly ash (FA) or ladle furnace slag (LFS) as precursors of alkali activation were studied and tested four different mixture composition, in accordance with the main aim of this study. The following are the main conclusions obtained:

- Different CR/FA (M1 and M2) and CR/LFS (M3 and M4) ratios were prepared and tested for the purpose. The UCS test was performed for each specimen after 1, 14, 28 and 90 days to determined the efficiency of the blends. The highest compressive strength $(59.95 \mathrm{MPa})$ was reached by the combination of 75CR-25 LFS/ $\mathrm{SS}$ at 90 days of curing. It can be stated that this resulting material is stiffer compared to the CR-FA/SH or SS mixture, where the highest strength in the same conditions was 20.26 MPa.

- M1-M2 and M3-M4 mixtures are calcium-poor or calcium-rich aluminosilicates, respectively, which is basically determined by the starting materials. Higher calcium content positively affects the strength of the mixture. As it was evidenced throughout the UCS results.

- The combination of the CR+FA precursors, regardless of the alkaline solution (SH or SS), enabled the formation of a cementitious geltype, namely, N-A-S-H. On the other hand, NC-A-S-H or C-A-S-H gels are identified, when $\mathrm{CR}+\mathrm{LFS}$ is activated whether $\mathrm{SH}$ or $\mathrm{SS}$, respectively.

\section{ACKNOWLEDGMENTS}

This work was supported by Portuguese funding through the Foundation for Science and Technology FCT/MCTES (PIDDAC), within the framework of the R\&D Project "JUSTREST - Development of Alkali Binders for Geotechnical Applications Made Exclusively from Industrial Waste", reference PTDC/ ECM-GEO/0637/2014.

The author would also like to acknowledge the support of the Secretary of Higher Education, 
Science, Technology and Innovation, SENESCYT (Spanish acronym) from Ecuador, reference No. CZ03-000052-2017.

\section{REFERENCES}

1. Hwang, C.-L.; Damtie Yehualaw, M.; Vo, D.-H.; Huynh, T.-P. (2019) Development of high-strength alkali-activated pastes containing high volumes of waste brick and ceramic powders. Constr. Build. Mater. 218, 519-529. https://doi.org/10.1016/j.conbuildmat.2019.05.143.

2. Eurostat. (2018) Waste statistics - Statistics Explained.

3. Cerame-Unie; Ceramic industry | Cerame-Unie - The European Ceramic Industry Association.

4. Khan, M.S.; Sohail, M.; Khattak, N.S.; Sayed, M. (2016) Industrial ceramic waste in Pakistan, valuable material for possible applications. J. Clean. Prod. 139, 1520-1528. https://doi.org/10.1016/j.jclepro.2016.08.131.

5. Chen, H.-J.; Yen, T.; Chen, K.-H. (2003) Use of building rubbles as recycled aggregates. Cem. Concr. Res. 33 [1], 125-132. https://doi.org/10.1016/S0008-8846(02)00938-9.

6. Jindal, A.; Ransinchung, R.N.G.D. (2018) Behavioural study of pavement quality concrete containing construction, industrial and agricultural wastes. Int. J. Pavement Res. Technol. 11 [5], 488-501. https://doi.org/10.1016/j. ijprt.2018.03.007.

7. Cristelo, N.; Fernández-Jiménez, A.; Miranda, T.; Palomo, Á. (2017) Sustainable alkali activated materials: Precursor and activator derived from industrial wastes. J. Clean. Prod. 162, 1200-1209. https://doi.org/10.1016/j. jclepro.2017.06.151

8. Gavali, H.R.; Bras, A.; Faria, P.; Ralegaonkar, R. V. (2019) Development of sustainable alkali-activated bricks using industrial wastes. Constr. Build. Mater. 215, 180-191. https://doi.org/10.1016/j.conbuildmat.2019.04.152.

9. Amin, S.K.; El-Sherbiny, S.A.; El-Magd, A.A.M.A.; Belal, A.; Abadir, M.F. (2017) Fabrication of geopolymer bricks using ceramic dust waste. Constr. Build. Mater. 157, 610-620. https://doi.org/10.1016/j.conbuildmat.2017.09.052.

10. Murillo, L.M.; Delvasto, S.; Gordillo, M. (2017) A study of a hybrid binder based on alkali-activated ceramic tile wastes and portland cement. In Sustainable and Nonconventional Construction Materials using Inorganic Bonded Fiber Composites. Elsevier Inc., pp. 291-311. https://doi.org/10.1016/B978-0-08-102001-2.00013-9.

11. Villaquirán-Caicedo, M.A.; de Gutiérrez, R.M. (2018) Synthesis of ceramic materials from ecofriendly geopolymer precursors. Mater. Lett. 230, 300-304. https://doi. org/10.1016/j.matlet.2018.07.128.

12. Azevedo, A.R.G.; Vieira, C.M.F.; Ferreira, W.M.; Faria, K.C.P.; Pedroti, L.G.; Mendes, B.C. (2020) Potential use of ceramic waste as precursor in the geopolymerization reaction for the production of ceramic roof tiles. J. Build. Eng. 29, 101156. https://doi.org/10.1016/j. jobe.2019.101156

13. Sun,Z.; Cui, H.; An, H.; Tao, D.; Xu, Y.;Zhai, J.; Li, Q. (2013) Synthesis and thermal behavior of geopolymer-type material from waste ceramic. Constr. Build. Mater. 49, 281-287. https://doi.org/10.1016/j.conbuildmat.2013.08.063.

14. Huseien, G.F.; Sam, A.R.M.; Shah, K.W.; Asaad, M.A.; Tahir, M.M.; Mirza, J. (2019) Properties of ceramic tile waste based alkali-activated mortars incorporating GBFS and fly ash. Constr. Build. Mater. 214, 355-368. https://doi. org/10.1016/j.conbuildmat.2019.04.154.
15. Reig, L.; Sanz, M.A.; Borrachero, M.V.; Monzó, J.; Soriano, L.; Payá, J. (2017) Compressive strength and microstructure of alkali-activated mortars with high ceramic waste content. Ceram. Int. 43 [16], 13622-13634. https://doi.org/10.1016/j.ceramint.2017.07.072.

16. Rakhimova, N.R.; Rakhimov, R.Z. (2015) Alkali-activated cements and mortars based on blast furnace slag and red clay brick waste. Mater. Des. $85,324-331$. https://doi. org/10.1016/j.matdes.2015.06.182.

17. Huseien, G.F.; Sam, A.R.M.; Shah, K.W.; Mirza, J.; Tahir, M.M. (2019) Evaluation of alkali-activated mortars containing high volume waste ceramic powder and fly ash replacing GBFS. Constr. Build. Mater. 210, 78-92. https:// doi.org/10.1016/j.conbuildmat.2019.03.194.

18. Huseien, G.F.; Sam, A.R.M.; Mirza, J.; Tahir, M.M.; Asaad, M.A.; Ismail, M.; Shah, K.W. (2018) Waste ceramic powder incorporated alkali activated mortars exposed to elevated Temperatures: Performance evaluation. Constr. Build. Mater. 187, 307-317. https://doi.org/10.1016/j. conbuildmat.2018.07.226

19. Cristelo, N.; Tavares, P.; Lucas, E.; Miranda, T.; Oliveira, D. (2016) Quantitative and qualitative assessment of the amorphous phase of a Class F fly ash dissolved during alkali activation reactions - Effect of mechanical activation, solution concentration and temperature. Compos. Part B Eng. 103, 1-14. https://doi.org/10.1016/j. compositesb.2016.08.001.

20. CCP14 Homepage - Tutorials and Examples - Powder Cell for Windows, Structure Visualisation/Manipulation, Powder Pattern Calculation and Profile Fitting by Werner Kraus and Gert Nolze

21. Le Bail, A (1995) Modelling the silica glass structure by the Rietveld method. J. Non. Cryst. Solids. 183, 39-42. https://doi.org/10.1016/0022-3093(94)00664-4.

22. Cristelo, N.; Coelho, J.; Miranda, T.; Palomo, Á. Fernández-Jiménez, A. (2019) Alkali activated composites - An innovative concept using iron and steel slag as both precursor and aggregate. Cem. Concr. Compos. 103, 11-21. https://doi.org/10.1016/j.cemconcomp.2019.04.024.

23. Ruiz-Santaquiteria, C.; Fernández-Jiménez, A.; Palomo, Á. (2016) Alternative prime materials for developing new cements: Alkaline activation of alkali aluminosilicate glasses. Ceram. Int. 42 [8], 9333-9340. https://doi. org/10.1016/j.ceramint.2016.03.111

24. Fernández-Jiménez, A. Monzó, M. Vicent, M.; Barba, A.; Palomo, Á. (2008) Alkaline activation of metakaolinfly ash mixtures: Obtain of Zeoceramics and Zeocements. Microporous Mesoporous Mater. 108 [1-3], 41-49. https:// doi.org/10.1016/j.micromeso.2007.03.024.

25. Garcia-Lodeiro, I.; Fernandez-Jimenez, A.; Palomo, Á. (2013) Hydration kinetics in hybrid binders: Early reaction stages. Cem. Concr. Compos. 39, 82-92. https://doi. org/10.1016/j.cemconcomp.2013.03.025.

26. Puertas, F.; Palacios, M.; Manzano, H.; Dolado, J.S.; Rico, A.: Rodríguez, J. (2011) A model for the C-A-S-H gel formed in alkali-activated slag cements. J. Eur. Ceram. Soc. 31 [12], 2043-2056. https://doi.org/10.1016/j.jeurceramsoc.2011.04.036.

27. Schneider, H.; Schreuer, J.; Hildmann, B. (2008) Structure and properties of mullite-A review. J. Eur. Ceram. Soc. 28 [2], 329-344. https://doi.org/10.1016/j.jeurceramsoc.2007.03.017.

28. Rivera, J.F.; Cristelo, N.; Fernández-Jiménez, A.; Mejía de Gutiérrez, R. (2019) Synthesis of alkaline cements based on fly ash and metallurgic slag: Optimisation of the $\mathrm{SiO}_{2}$ $/ \mathrm{Al}_{2} \mathrm{O}_{3}$ and $\mathrm{Na}_{2} \mathrm{O} / \mathrm{SiO}_{2}$ molar ratios using the response surface methodology. Constr. Build. Mater. 213, 424-433. https://doi.org/10.1016/j.conbuildmat.2019.04.097. 